\title{
MODEL KEGIATAN MICROTEACHING UNTUK MENGEMBANGKAN KETERAMPILAN MELAKSANAKAN PEMBELAJARAN MATEMATIKA BERPUSAT PADA SISWA
}

\author{
Susilahudin Putrawangsa ${ }^{1}$, Muhammad Syawahid ${ }^{2}$ \\ ${ }^{1,2}$ Pendidikan Matematika, Fakultas Tarbiyah dan Keguruan, UIN Mataram \\ putrawangsa@uinmataram.ac.id
}

\begin{abstract}
Abstrak
Penelitian ini bertujuan untuk mengidentifikasi karakteristik model kegiatan Microteaching yang valid, efektif, dan praktis untuk membangun keterampilan mahasiswa calon guru matematika dalam melaksanakan pembelajaran berpusat pada siswa (student centered). Penelitian ini adalah penelitian pengembangan yang dilaksanakan menggunakan kerangka kerja Educational Design Research. Hasil penelitian ini menunjukkan bahwa karakteristik kegiatan Microteaching untuk membangun keterampilan mahasiswa calon guru matematika dalam melaksanakan pembelajaran berpusat pada siswa antara lain: (1) Kegiatan microteaching dilaksanakan dalam siklus kegiatan perencanaan, pelaksanaan, observasi, dan evaluasi pembelajaran student centered dimana setiap peserta berganti peran sebagai guru dan penilai; (2) Kegiatan microteaching dilaksanakan dalam bentuk peer microteaching oleh sekelompok pembelajar mandiri (self-study group) dimana mereka saling menilai (peer supervision); (3) Kegiatan microteaching memiliki protokol observasi dan evaluasi guru yang dilakukan oleh diri peserta (self evaluation) dan sejawat (peer evaluation) serta fokus pada aspek penampilan mengajar guru terkait dengan keterampilan melaksanakan pembelajaran berpusat pada siswa yang dianggap sangat penting dan mungkin untuk diperbaiki pada saat kegiatan microteaching berlangsung (at-the-time improvement); dan (4) Kegiatan microteaching dilaksanakan dalam suasana pembelajaran dengan kompleksitas yang progresif, yaitu mulai dari mengejar pada kelas dengan pengaturan kompleksitas rendah ke tinggi.
\end{abstract}

Kata Kunci: Microteaching, Pembelajaran Matematika, Pembelajaran Berpusat pada Siswa

\begin{abstract}
The current research intends to identify the characteristics of microteaching model that is valid, effective and practical to develop prospective mathematics teachers' competencies in conducting student-centered instructions. It is a development research carried out according to Educational Design Research. The findings suggests that the characteristics of microteaching model to develop prospective mathematics teachers' competencies in conducting student-centered instructions are: (1) a microteaching which is carried out in a cycle process consisting of planning, implementing, observing, and evaluating studentcentered teaching and learning where each participant acts as a teacher and evaluators in turn. (2) a microteaching that is conducted in form of Peer Microteaching by Self-Study Group where they peer supervise each other (Peer Supervision). (3) a microteaching that has a teacher observation and evaluation protocol that is conducted by themselves (Selfevaluation) and others (Peer Evaluation) and focuses on particular aspects of teacher performance in implementing student-centered instructions those are claimed to important and possible to be refined at the moment (At-the-time improvement). (4) a microteaching which is carried out in a progressive complexity of teaching environment, that is starting from teaching a less complex to a more complex classroom setting.
\end{abstract}

Keywords: Microteaching, Mathematics Instruction, Student Centered Learning 


\section{PENDAHULUAN}

Dewasa ini, paradgima pembelajaran matematika telah mengalami perubahan yang signifikan, yang mulanya berpusat pada guru kini beralih pada pembelajaran matematika yang berpusat pada siswa (lihat NCTM, 2000; Mendiknas, 2006; Singapore Ministry of Education, 2012; Mendikbud, 2016). Perubahan paradigma ini secara langsung mempengaruhi kompetensi pedagogik yang harus dimiliki oleh guru untuk memenuhi standar pembelajaran yang berpusat pada siswa. Salah satu kompetensi pedagogik tersebut adalah keterampilan guru dalam melaksanakan pembelajaran yang berpusat pada siswa, yaitu suatu model pembelajaran yang didasarkan pada prinsip dan teori belajar konstruktivis, dimana teori ini memandang bahwa siswa adalah pusat dari proses pembelajaran dan mereka aktif serta bertanggung jawab penuh atas pembelajaran tersebut (Anthony, 1996; Weltman, 2007).

Selain berdampak terhadap guru, perubahan paradigma pembelajaran tersebut juga berimplikasi pada mahasiswa calon guru matematika, dimana calon guru matematika seharusnya disiapkan untuk dapat melaksanakan pengajaran berpusat pada siswa guna menjawab tantangan perubahan paradigma tersebut. Terkait dengan hal ini, kegiatan perkuliahan Microteaching dapat dijadikan sebagai salah satu alternatif jalan untuk membangun keterampilan mahasiswa calon guru dalam melaksanakan pembelajaran berpusat pada siswa. Hal ini dikarenakan Microteaching adalah bentuk kegiatan yang khusus dikembangkan untuk meningkatkan profesionalitas guru yang tujuan utamanya adalah peningkatan kualitas kemampuan dan keahlian guru dalam melaksanakan pembelajaran (Koc dkk., 2016; Ferna'ndez, 2010; Karçkay dkk., 2009).

Meskipun berbagai penelitian membuktikan bahwa Microteaching efektif untuk meningkatkan kapasitas guru (Koc dkk., 2016; Ferna'ndez, 2010; Karçkay dkk., 2009), hingga saat ini belum ditemukan model kegiatan Microteaching yang secara spesifik bertujuan untuk mengembangkan keterampilan guru dalam melaksanakan pembelajaran berpusat pada siswa. Sebagian besar riset terkait dengan Microteaching lebih banyak terfokus pada investigasi pengaruh, dampak atau efektivitas kegiatan Microteaching terhadap peningkatkan keterampilan mengajar, seperti penelitian yang dilakukan oleh Ferna'ndez (2010), Bell (2007), Higgins dkk. (2003); McNamara dkk. (2002) dan Altuk dkk. (2012).

Pengembangan model Microteaching pernah dilakukan oleh Allen and Wang (1996). Akan tetapi, mereka mengembangkan karakteristik umum kegiatan Microteaching, dimana dalam penelitian tersebut diperkenalkan tiga konsep dasar pelaksanaan kegiatan Microteaching, yaitu Self-Study Group, The 2+2 Evaluation Protocol, dan Peer Supervision. 
Berdasarkan urgensi dan limitasi seperti yang dijelaskan di atas, maka dipandang perlu untuk melakukan penelitian guna menemukan karakteristik dari model kegiatan Microteaching yang berorientasi pada penanaman keterampilan calon guru matematika dalam melaksanakan pembelajaran berpusat pada siswa guna mempersiapkan mereka menghadapi perubahan paradigma dan tuntutan pembelajaran matematika dewasa ini.

\section{METODE}

Karena penelitian ini bertujuan untuk mengembangkan model kegiatan microteaching yang meliputi karakteristik dari model tersebut berserta perangkat yang yang diperlukan untuk menjamin penerapan model tersebut dengan baik, penelitian ini adalah penelitian pengembangan yang dilakukan dalam kerangka kerja Educational Design Research yang terdiri atas tiga tahapan pengembangan, yaitu studi pendahuluan (preliminary research), perancangan dan pengembangan (prototyping), dan analisis proses pengembangan (retrospective analysis) (Plomp \& Nieveen, 2010; McKenney \& Reeves, 2012; Akker dkk., 2006; Putrawangsa, dkk., 2013; Negara \& Putrawangsa, 2017).

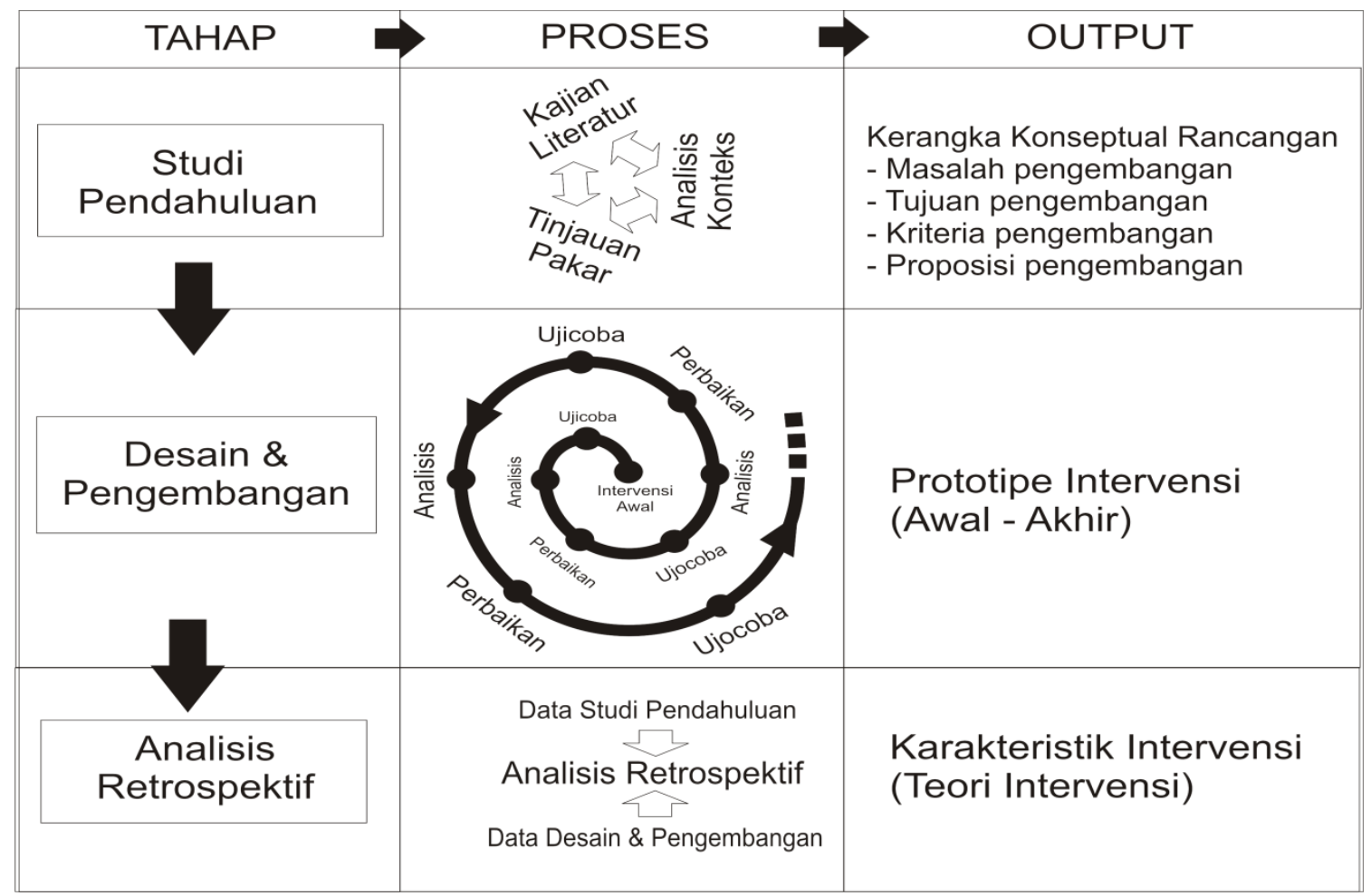

Gambar 1. Desain Penelitian 


\section{Tahap studi pendahuluan (preliminary research)}

Pada bagian ini, analisis konteks penelitian, tinjauan literatur dan konsultasi pakar dilakukan secara intensif dan masif sebagai dasar perumusan kerangka konseptual pengembangan, yaitu (1) rumusan masalah pengembangan, (2) tujuan pengembangan, (3) kriteria model intervensi, dan (4) proposisi (dugaan) awal model intervensi. Intervensi dalam penelitian ini merujuk pada model kegiatan microteaching yang akan dikembangkan.

\section{Tahap desain dan pengembangan intervensi (prototyping)}

Berdasarkan kerangka konseptual pengembangan yang telah dirumuskan pada tahapan sebelumnya, peneliti kemudian merancang bentuk awal intervensi, yaitu model awal kegiatan microteaching yang kemudian disebut sebagai prototipe awal.

Selanjutnya, validitas isi dan konstruksi terhadap prototipe awal dilakukan dengan melibatkan sejumlah pakar. Validitas isi dalam hal meninjau apakah prototipe awal sudah didasarkan atau relevan dengan keilmuan yang terkait (state-of-the-art knowledge). Sedangkan, validitas konstruksi merujuk pada apakah setiap komponen pembentuk rancangan saling berkaitan secara suportif dan logis antara yang satu dengan yang lainnya (logical order). Hasil dari proses validasi ini kemudian dijadikan sebagai dasar untuk memperbaiki prototipe awal yang kemudian menghasilkan prototipe 1 .

Selanjutnya prototipe 1 diujicoba di lapangan guna menguji efektivitas dan kepraktisannya. Uji efektivitas dalam hal ini merujuk pada mengukur apakah prototipe tersebut menghasilkan hasil yang diharapkan atau dihipotesiskan dengan mudah, yaitu apakah prototipe tersebut dapat digunakan untuk mencapai tujuan yang ingin diraih. Sedangkan kepraktisan intervensi merujuk pada apakah prototipe tersebut dapat diterapkan dengan mudah oleh pengguna dalam penerapannya. Hasil uji tersebut dijadikan dasar untuk meningkatkan kualitas prototipe. Uji efektivitas dan kepraktisan intervensi ini terus dilakukan hingga menemukan model intervensi yang dianggap ideal atau cukup ideal. Dalam penelitian ini, uji efektivitas dan kepraktisan intervensi dilakukan dalam 5 siklus. Dalam proses pengujian tersebut, peneliti juga melakukan sejumlah perubahan isi dan konstruksi guna meningkatkan validitas intervensi.

Dapat disimpulkan bahwa kegiatan pada tahapan ini sesungguhnya adalah kegiatan evaluasi formatif terhadap intervensi yang dikembangkan, yang dilaksankan dalam siklus kegiatan yang terdiri atas kegiatan (1) perancangan intervensi (designing), (2) ujicoba intervensi (experimenting), (3) analisis hasil ujicoba (analysis) dan (4) perbaikan intervensi (re-designing to refine). 
3. Tahap analisis retrospektif proses pengembangan (retrospective analysis)

Pada tahap ini, peneliti sudah memiliki rumusan intervensi yang telah diujicoba pada tahap sebelumnya (prototyping), yaitu perangkat kegiatan microteaching yang dipandang ideal untuk mencapai tujuan pengembangan. Selanjutnya, peneliti melakukan kajian retrospektif terhadap proses pengembangan pada dua tahap sebelumnya (tahap studi pendahuluan dan tahap desain dan pengembangan) guna merumuskan karakteristik dari intervensi tersebut (teori intervensi). Dalam penelitian ini teori intervensi yang dimaksud adalah karakteristik dari model kegiatan microteaching yang valid, efektif, dan praktis untuk mengembangkan keterampilan siswa dalam melaksanakan pembelajaran berpusat pada siswa. Analisis retrospektif dilakukan dengan menganalisis data dari dua tahap sebelumnya, yaitu tahap studi pendahuluan dan tahap desain dan pengembangan.

Ketiga tahapan pengembangan dalam penelitian ini seperti yang dijelaskan pada gambar 1 di atas dipaparkan lebih rinci pada Tabel 1.

Tabel 1. Tahapan Penelitian, Metode Pengumpulan dan Analisis Data

\begin{tabular}{|c|c|c|c|c|}
\hline Tahapan & $\begin{array}{c}\text { Studi } \\
\text { Pendahuluan }\end{array}$ & \multicolumn{2}{|c|}{ Desian dan Pengembangan Intervensi } & $\begin{array}{c}\text { Analisis } \\
\text { Retrospektif } \\
\text { Proses } \\
\text { Pengembangan } \\
\end{array}$ \\
\hline Kegiatan & $\begin{array}{l}\text { (1) Tinjauan } \\
\text { literatur, (2) } \\
\text { analisis } \\
\text { konteks, dan } \\
\text { (3) diskusi } \\
\text { pakar }\end{array}$ & $\begin{array}{l}\text { (1) Merumuskan } \\
\text { intervensi awal; (2) Uji } \\
\text { validitas intervensi, (3) } \\
\text { Uji efektivitas dan } \\
\text { kepraktisan dilakukan } \\
\text { berbasis asumsi logis } \\
\text { dan teoritis. }\end{array}$ & $\begin{array}{l}\text { (1) Uji efektivitas } \\
\text { dan kepraktisan } \\
\text { intervensi dalam } \\
\text { siklus kegiatan } \\
\text { perancangan, } \\
\text { ujicoba, analisis, } \\
\text { dan perbaikan; (2) } \\
\text { Uji validitas } \\
\text { dilakukan jika } \\
\text { diperlukan. }\end{array}$ & $\begin{array}{l}\text { Melakukan analisis } \\
\text { retrospektif atas } \\
\text { proses } \\
\text { pengembangan } \\
\text { yang telah } \\
\text { dilakukan }\end{array}$ \\
\hline Output & $\begin{array}{l}\text { Kerangka } \\
\text { Konseptual } \\
\text { Pengembangan }\end{array}$ & Prototipe Awal & Prototipe 1 sampai 5 & $\begin{array}{l}\text { Karakteristik } \\
\text { intervensi (Teori } \\
\text { Intervensi) }\end{array}$ \\
\hline $\begin{array}{l}\text { Keterlibata } \\
\mathrm{n}\end{array}$ & $\begin{array}{l}\text { Pakar sebagai } \\
\text { narasumber }\end{array}$ & Pakar sebagai validator & $\begin{array}{l}24 \text { peserta sebagai } \\
\text { responden (subjek) }\end{array}$ & Pakar dan Peserta \\
\hline $\begin{array}{l}\text { Pengumpul } \\
\text { an Data }\end{array}$ & $\begin{array}{l}\text { Dokumen, } \\
\text { Observasi, dan } \\
\text { Wawancara }\end{array}$ & $\begin{array}{l}\text { Dokumen, Observasi } \\
\text { dan Wawancara }\end{array}$ & $\begin{array}{l}\text { Observasi dan } \\
\text { Wawancara }\end{array}$ & $\begin{array}{l}\text { Dokumen, } \\
\text { Observasi, } \\
\text { Wawancar, dan } \\
\text { Angket }\end{array}$ \\
\hline $\begin{array}{l}\text { Analisis } \\
\text { Data }\end{array}$ & $\begin{array}{l}\text { Menemukan } \\
\text { relevansi dari } \\
\text { literatur, } \\
\text { konteks, dan } \\
\text { pakar. }\end{array}$ & $\begin{array}{l}\text { (1) Memetakan dan } \\
\text { menerjemahkan } \\
\text { proposisi rancangan ke } \\
\text { dalam bentuk intervensi } \\
\text { yang akan diujicoba. } \\
\text { (2) Memetakan dan } \\
\text { mengecek keabsahan } \\
\text { feedback dari pakar }\end{array}$ & $\begin{array}{l}\text { Mengkomparasi } \\
\text { antara proposisi } \\
\text { rancangan dengan } \\
\text { data hasil ujicoba } \\
\text { guna menguji } \\
\text { kebenaran hipotesis } \\
\text { pada proposisi } \\
\text { rancangan. }\end{array}$ & $\begin{array}{l}\text { Seluruh data proses } \\
\text { pengembangan } \\
\text { diorganisir ditinjau } \\
\text { secara } \\
\text { komprehensip, } \\
\text { holistik, integratif } \\
\text { dan mendalam } \\
\text { guna menemukan }\end{array}$ \\
\hline
\end{tabular}




\begin{tabular}{|c|c|c|c|}
\hline Tahapan & $\begin{array}{c}\text { Studi } \\
\text { Pendahuluan }\end{array}$ & Desian dan Pengembangan Intervensi & $\begin{array}{c}\text { Analisis } \\
\text { Retrospektif } \\
\text { Proses } \\
\text { Pengembangan } \\
\end{array}$ \\
\hline & & $\begin{array}{l}\text { serta } \\
\text { mengintegrasikannya } \\
\text { dalam intervensi. }\end{array}$ & $\begin{array}{l}\text { alasan logis yang } \\
\text { mendasari } \\
\text { terbuktinya } \\
\text { proposisi } \\
\text { rancangan di } \\
\text { lapangan. }\end{array}$ \\
\hline
\end{tabular}

\section{HASIL DAN PEMBAHASAN}

\section{Hasil Penelitian}

Pada bagian ini akan dipaparkan hasil penelitian ini yang merupakan prototipe terakhir dari serangakian proses pengembangan model kegiatan microteaching. Paparan ini dimulai dari pemaparan orientasi kegiatan microteaching, kemudian dilanjutkan dengan paparan tahapan kegiatan microteaching yang dipandang valid, efektif dan praktis untuk mencapai orientasi tersebut.

Orientasi kegiatan Microteaching dalam penelitian ini adalah untuk mengembangkan keterampilan mengajar mahasiswa calon guru matematika dalam melaksanakan pembelajaran yang berpusat pada siswa (Student Centered Learning). Keterampilan-keterampilan tersebut meliputi keterampilan membuka pembelajaran, mengelola pembelajaran berbasis diskusi kelompok dan diskusi kelas, dan menutup pembelajaran (Lihat Tabel 2).

Tabel 2. Fokus Keterampilan Microteaching dalam Penelitian ini

\begin{tabular}{|c|c|c|}
\hline No & $\begin{array}{c}\text { Fokus } \\
\text { Keterampilan }\end{array}$ & Keterangan \\
\hline 1 & $\begin{array}{l}\text { Membuka } \\
\text { pembelajaran }\end{array}$ & $\begin{array}{l}\text { - Keterampilan memulai pembelajaran sedemikian sehingga } \\
\text { siswa memiliki sikap mental yang fokus untuk belajar, } \\
\text { termotivasi, dan memiliki rasa ingin tahu. } \\
\text { - Keterampilan memilih bentuk dan materi kegiatan awal } \\
\text { pembelajaran yang relevan dengan kegiatan inti pembelajaran. }\end{array}$ \\
\hline 2 & $\begin{array}{l}\text { Mengelola } \\
\text { pembelajaran } \\
\text { dalam diskusi } \\
\text { kelompok }\end{array}$ & $\begin{array}{l}\text { - Keterampilan guru dalam merancang masalah pembelajaran } \\
\text { yang relevan dengan tujuan pembelajaran, serta realistis dan } \\
\text { menarik bagi siswa. } \\
\text { - Keterampilan guru dalam memperkenalkan masalah } \\
\text { pembelajaran sedemikian sehingga siswa memahami duduk } \\
\text { masalahnya dan tertarik untuk menyelesaikannya. } \\
\text { - Keterampilan guru dalam memberikan arahan, stimulus atau } \\
\text { triger (melakukan tindakan sedemikian sehingga secara tidak } \\
\text { langsung berdampak pada tindakan siswa yang mengarah pada } \\
\text { apa yang dihaparkan). } \\
\text { - Keterampilan guru menjaga kondusifitas kegiatan diskusi } \\
\text { kelompok. }\end{array}$ \\
\hline 3 & Mengelola & - Keterampilan guru dalam memilih dan memanfaatkan solusi \\
\hline
\end{tabular}




\begin{tabular}{|c|c|c|}
\hline No & $\begin{array}{c}\text { Fokus } \\
\text { Keterampilan }\end{array}$ & Keterangan \\
\hline & $\begin{array}{l}\text { pembelajaran } \\
\text { dalam diskusi } \\
\text { kelas }\end{array}$ & $\begin{array}{l}\text { siswa sebagai bahan diskusi kelas untuk mencapai tujuan } \\
\text { pembelajaran (penanaman konsep). } \\
\text { - Keterampilan guru dalam mengarahkan pikiran dan } \\
\text { pembicaraan siswa pada diskusi kelas untuk mencapai tujuan } \\
\text { pembelajaran (penanaman konsep). } \\
\text { - Keterampilan guru dalam memberikan arahan, stimulus atau } \\
\text { triger sedemikian sehingga siswa terlibat aktif dalam kegiatan } \\
\text { diskusi kelas. } \\
\text { - Keterampilan guru menjaga kondusifitas kegiatan diskusi kelas. }\end{array}$ \\
\hline 4 & $\begin{array}{l}\text { Menutup } \\
\text { pembelajaran }\end{array}$ & $\begin{array}{l}\text { - Keterampilan guru dalam memfasilitasi siswa dalam } \\
\text { merumuskan kesimpulan dari kegiatan pembelajaran yang telah } \\
\text { dilalui. } \\
\text { - Keterampilan guru dalam melaksanakan kegiatan lanjutan } \\
\text { (follow-up activities) untuk menguatkan pemahaman siswa } \\
\text { tentang konsep pada tujuan pembelajaran. }\end{array}$ \\
\hline
\end{tabular}

Setelah melalui serangkaian kegiatan eksperimen dan revisi, kegiatan microteaching yang dipandang valid, efektif, dan praktis untuk mengembangkan keempat fokus keterampilan di atas yaitu kegiatan microteaching yang melibatkan peserta dalam rangkaian kegiatan microteaching berikut ini:

1. Perancangan Pembelajaran

Sebelum melaksanakan praktik mengajar, setiap peserta merancang sebuah kegiatan pembelajaran student centered berdurasi 35 - 40 menit. Pembelajaran student centered yang dirancang terdiri atas tiga tahap kegiatan pembelajaran, yaitu: kegiatan awal pembelajaran, kegiatan inti pembelajaran, dan kegiatan akhir pembelajaran (Lihat Tabel 3). Sebelum diterapkan, rancangan tersebut didiskusikan dengan peserta lainnya dan juga kepada dosen pembimbing untuk mendapatkan masukan guna meningkatkan kualitas rancangan tersebut.

Dalam rancangan pembelajaran tersebut, peserta diarahkan untuk memilih tujuan, materi dan kegiatan pembelajaran yang sesuai dengan perkembangan kognitif peserta yang akan bertindak sebagai siswa pada kegiatan microteaching. Hal ini bertujuan untuk menghadirkan tantangan dan suasana pembelajaran yang mendekati tantangan dan suasana pembelajaran sesungguhnya.

Tabel 3. Pedoman Rancangan Kegiatan Pembelajaran

\begin{tabular}{ll}
\hline Kegiatan & \multicolumn{3}{c}{ Keterangan } \\
\hline Awal & Pada kegiatan awal, peserta merencanakan kegiatan pembelajaran \\
& yang bertujuan untuk mempersiapkan siswa guna menghadapi \\
& kegiatan inti. Bentuk dari kegiatan awal dapat berupa: \\
& - Kegiatan apersepsi guna menumbuhkan ketertarikan dan motivasi \\
\hline
\end{tabular}




\begin{tabular}{ll}
\hline Kegiatan & \multicolumn{1}{c}{ Keterangan } \\
\hline & siswa dan mempersiapkan mental dan konsentrasi siswa untuk \\
& belajar; \\
- & review pembelajaran atau penyampaian fakta-fakta penting yang \\
& memiliki kaitan atau prasyarat dari kegiatan inti sedemikian \\
& sehingga siswa memiliki landasan berpikir untuk menyelesaikan \\
& masalah yang diberikan pada kegiatan inti nantinya. \\
\hline Inti & Untuk mencapai tujuan pembelajaran, kegiatan inti dirancang dalam \\
tiga tahapan kegiatan pembelajaran yang saling terkait satu dengan \\
yang lain, yaitu pertama kegiatan pengenalan masalah, penyelesaian \\
masalah dalam diskusi kelompok; dan dilanjutkan dengan diskusi \\
kelas. \\
- Pengenalan Masalah \\
Pada bagian ini, peserta merancang masalah pembelajaran yang \\
relevan untuk mencapai tujuan pembelajaran disertai dengan \\
strategi penyampaiannya kepada siswa. \\
- Diskusi Kelompok \\
Pada bagian ini, peserta merancang setting kegiatan diskusi \\
kelompok siswa yang bertujuan untuk menyelesaikan masalah yang \\
diberikan dalam kelompok kecil, termasuk dalam rancangan \\
tersebut adalah rumusan peranan guru selama diskusi kelompok \\
berlangsung. \\
- Diskusi Kelas \\
Pada bagian ini, peserta merancang setting kegiatan diskusi kelas \\
yang bertujuan untuk menyelesaikan masalah yang diberikan dalam \\
kelompok yang lebih besar, termasuk dalam rancangan tersebut \\
adalah rumusan peranan guru selama diskusi kelas berlangsung. \\
Pada kegiatan ini, peserta merancang kegiatan pembelajaran yang \\
bertujuan untuk membantu siswa menyimpulkan pembelajaran dan \\
juga kegiatan untuk memperkuat pemahaman siswa. Dalam hal ini, \\
peserta merancang kegiatan yang memungkinkan siswa secara \\
bersama-sama menyimpulkan hasil pembelejaran dengan panduan \\
guru. Selain itu, peserta merancang kegiatan lanjutan untuk \\
menguatkan pemahaman siswa, seperti soal latihan. \\
\hline Akhir
\end{tabular}

2. Pelaksanaan Pembelajaran (Praktik Mengajar)

Rancangan pembelajaran yang telah disusun oleh peserta kemudian diimplementasikan dalam suatu pembelajaran. Dalam model ini, kegiatan microteaching dibagi menjadi dua tahapan. Pada microteaching tahap pertama, pembelajaran dilakukan dalam kelompok kecil yang terdiri atas 6-7 peserta (1 peserta sebagai guru dan 5-6 peserta sebagai siswa sekaligus bertindak sebagai observer). Namun pada microteaching tahap kedua, pembelajaran dilakukan dalam kelompok yang lebih besar, yaitu beranggotakan $12-14$ peserta per kelompok. Peralihan microteaching tahap pertama ke tahap kedua dilakukan jika setiap peserta telah mendapatkan giliran sebagai guru pada microteaching tahap pertama. 
3. Observasi Pelaksanaan Pembelajaran

Pada pelaksanaan pembelajaran, pada saat yang bersamaa peserta yang berperan sebagai siswa juga berperan sebagai observer kegiatan pembelajaran. Untuk melakukan observasi tersebut, peserta dibekali dengan pedoman observasi (Tabel 4). Pedoman observasi tersebut disampaikan jauh sebelum kegiatan microteaching dilakukan agar menjadi pemahaman bersama sehingga observer yang saat bersamaan berperan sebagai siswa sudah memiliki bayangan aspek apa yang harus diamati dari penampilan mengajar guru.

Tabel 4. Pedoman Observasi Pelaksanaan Pembelajaran

\begin{tabular}{|c|c|}
\hline Kegiatan & Fokus Observasi pada Setiap Tahap Pembelajaran \\
\hline $\begin{array}{l}\text { Kegiatan } \\
\text { Awal } \\
\text { Pembelajaran }\end{array}$ & $\begin{array}{l}\text { - Sejauh mana keberhasilan guru membuka pembelajaran sedemikian } \\
\text { sehingga dapat mempersiapkan mental siswa untuk belajar? } \\
\text { - Sejauh mana kegiatan awal pembelajaran mempersiapkan siswa } \\
\text { untuk menghadapi kegiatan inti pembelajaran, yaitu apakah kegiatan } \\
\text { awal pembelajaran menyediakan landasan berpikir bagi siswa untuk } \\
\text { menyelesaikan masalah pada kegiatan inti? }\end{array}$ \\
\hline $\begin{array}{l}\text { Diskusi } \\
\text { Kelompok }\end{array}$ & $\begin{array}{l}\text { - Apakah guru berhasil menyampaikan masalah pembelajaran } \\
\text { sedemikian sehingga setiap siswa memahami dengan baik masalah } \\
\text { pembelajaran yang akan didiskusikan? } \\
\text { - Apakah penyajian masalah pembelajaran yang disediakan guru dapat } \\
\text { membantu siswa untuk mencapai tujuan pembelajaran? } \\
\text { - Bagaimana usaha guru dalam menstimulus siswa agar terus berpikir } \\
\text { dan mencoba guna menemukan solusi terhadap masalah yang } \\
\text { diberikan? }\end{array}$ \\
\hline $\begin{array}{l}\text { Diskusi } \\
\text { Kelas }\end{array}$ & $\begin{array}{l}\text { - Apakah guru berhasil mengelola kegiatan diskusi kelas sedemikian } \\
\text { sehingga setiap siswa terlibat aktif dalam kegiatan tersebut? } \\
\text { - Bagaimana usaha guru dalam mengarahkan diskusi kelas sedemikian } \\
\text { sehingga diskusi kelas mengarah pada tercapainya tujuan } \\
\text { pembelajaran? }\end{array}$ \\
\hline $\begin{array}{l}\text { Kegiatan } \\
\text { Akhir } \\
\text { Pembelajaran }\end{array}$ & $\begin{array}{l}\text { - Sejauh mana keberhasilan guru membimbing siswa dalam } \\
\text { menyimpulkan pembelajaran? } \\
\text { - Apakah kegiatan akhir yang dilakukan guru menguatkan penguasaan } \\
\text { siswa terhadap tujuan pembelajaran? }\end{array}$ \\
\hline
\end{tabular}

4. Evaluasi Pelaksanaan Pembelajaran

Setalah pelaksanaan pembelajaran, kelompok peserta microteaching langsung mendiskusikan kegiatan pembelajaran tersebut untuk dievaluasi. Kegiatan evaluasi ini dilakukan dalam tiga tahapan, yaitu pertama-tama guru melakukan evaluasi diri guru (self evaluation), kemudian evaluasi dari observer (peer evaluation), dan selanjutnya guru dan observer bersama-sama mendiskusikan hal-hal yang perlu dilakukan untuk memperbaiki kualitas pengajaran guru. Sebagai pedoman kegiatan 
evaluasi, peneliti mengembangkan protokol evaluasi seperti yang ditunjukkan pada Tabel 5.

Evaluasi penampilan mengajar guru difokuskan pada dua poin, yaitu pertama hal yang dianggap sudah baik dari penampilan guru (good points) dan kedua hal yang perlu diperbaiki dari penampilan guru (correction points). Metode observasi ini diperkenalkan dengan istilah $G \& C$ Evaluation Protocol (Good and Correction Evaluation Protocol). Pada Good Points, tim observer diharuskan mengungkapkan 2 atau 3 hal yang dianggap paling penting dan urgen untuk disampaikan kepada peserta yang bertindak sebagai guru untuk dipertahankan dan bila perlu ditingkatkan. Sedangkan pada Correction Points, tim observer diharuskan untuk menyampaikan 2 atau 3 hal yang dianggap paling penting dan urgen terkait dengan penampilan mengajar guru untuk diperbaiki dan lebih lanjut untuk didiskusikan bersama solusi perbaikannya.

Tabel 5. Protokol Kegiatan Evaluasi

\begin{tabular}{ll}
\hline Kegiatan & \multicolumn{1}{c}{ Deskripsi Kegiatan } \\
\hline Evaluasi & Guru merefleksi kegiatan pembelajaran yang telah dilakukannya. \\
Diri oleh & Evaluasi diri dilakukan dengan menanggapi pertanyaan-pertanyaan \\
Guru & berikut ini: \\
& - Bagian proses pengajaran yang mana yang sudah Anda lakukan \\
& dengan baik? Mengapa? \\
& - Bagian proses pengajaran yang mana yang belum Anda lakukan \\
& dengan baik? Mengapa? \\
& - Apa inspirasi yang Anda dapatkan dari pengalaman mengajar saat ini \\
& untuk memperbaiki kualitas pengajaran Anda di masa akan datang? \\
\hline Evaluasi & Tim observer menyampaikan masukan untuk guru terkait dengan hal \\
Rekan & yang sudah baik (Good Points) dan hal yang masih kurang baik \\
Sejawat & Correction Points) dari pengajaran guru. \\
& - Good Point \\
& Tim observer mengungkapkan 2 atau 3 hal yang dianggap paling \\
& penting dan urgen untuk disampaikan kepada guru untuk \\
& dipertahankan dan bila perlu ditingkatkan. \\
& Correction Point \\
& Tim observer menyampaikan 2 atau 3 hal yang dianggap paling \\
& penting dan urgen terkait dengan penampilan mengajar guru untuk \\
& diperbaiki. Solusi perbaikan atas kelemahan guru ini lebih lanjut \\
& akan didiskusikan bersama pada tahap evaluasi berikutnya, yaitu \\
diskusi guru-observer. & \\
\hline Diskusi & Tim observer dan guru bersama-sama mendiskusikan solusi atas \\
kelemahan guru dalam pembelajaran (Correction Points). Solusi yang \\
Observer & $\begin{array}{l}\text { dianggap relevan selanjutnya akan diterapkan oleh guru dalam } \\
\text { pembelajaran ulang, yaitu guru pada saat itu juga memperbaiki } \\
\text { penampilan mengajarnya (at-the-time improvement). }\end{array}$ \\
\hline &
\end{tabular}


5. Pengajaran Ulang dan Evaluasi Pengajaran Ulang

Dengan memperhatikan hasil evaluasi, guru melaksanakan kembali pembelajaran. Dalam kesempatan ini, guru mencoba menerapkan solusi yang didapatkan pada kegiatan evaluasi.

Dalam praktik pengajaran ulang ini, guru membelajarkan materi yang sama dengan pembelajaran sebelumnya akan tetapi dengan masalah pembelajaran yang berbeda dari pembelajaran sebelumnya. Hal ini diperlukan guna mempertahankan respon siswa dan suasana pembelajaran yang natural.

Seperti pada kegiatan pembelajaran sebelumnya, tim observer bertindak sebagai siswa dan pada saat yang bersamaan mengobservasi pembelajaran ulang yang dilakukan guru. Berbeda dengan observasi pada pembelajaran sebelumnya, fokus observasi pada pembelajaran kali ini adalah pada usaha guru untuk memperbaiki penampilan mengajarnya dengan memperhatikan masukan dan saran yang telah didapatkan sebelumnya. Selain itu, pengajaran ulang ini dijadikan sebagai verifikator, apakah saran perbaikan yang akan diterapkan memang benar dapat meningkatakan kualitas pengajaran guru.

Setelah pembelajaran ulang dilakukan oleh guru, tim observer bersama guru mengevalusi kembali pembelajaran yang dilakukan guru. Evaluasi ini difokuskan pada 2 hal. Pertama, apakah guru sudah berusaha menerapkan saran dari evaluasi sebelumnya. Kedua, sejauhmana efektifitas saran tersebut dalam meningkatkan keterampilan mengajar guru.

\section{Pembahasan}

Bagian ini akan memaparkan karakteristik dari model microteaching dari hasil penelitian ini. Sejumlah komparasi dilakukan untuk memperjelas persamaan atau perbedaan model microteaching ini jika dibandingkan dengan model microteaching lainnya.

Ditinjau dari orientasi kegiatan microteaching, model microteaching dalam penelitian ini memiliki orientasi yang spesifik dan terukur, yaitu menanmkan keterampilan peserta dalam melaksanakan pembelajaran berpusat pada siswa yang terdiri atas empat keterampilan utama, yaitu keterampilan mengawali pembelajaran, keterampilan mengelola diskusi kelompok, keterampilan mengelola diskusi kelas, dan keterampilan mengakhiri kegiatan pembelajaran. Hal ini sejalan dengan pandangan Allen \& Wang, (1996) dan Ferna'ndez (2010) yang menegaskan bahwa microteaching adalah bentuk kegiatan pelatihan praktik 
pembelajaran yang disedeharanakan yang bertujuan untuk meningkatkan kualitas kemampuan mengajar calon guru pada fokus keterampilan tertentu.

Model kegiatan Microteaching dalam penelitian secara umum adalah sebuah siklus kegiatan yang terdiri atas tiga kegiatan berbeda, yaitu perancangan pembelajaran, pelaksanaan pembelajaran, dan evaluasi pembelajaran. Kegiatan observasi pembelajaran merupakan bagian dari kegiatan evaluasi pembelajaran.

Berbeda dengan model microteaching pada D. Allen yang cenderung membatasi sejumlah faktor-faktor yang mempengaruhi pembelajaran, seperti waktu, jumlah siswa dan fokus keterampilan (Allen \& Wang, 1996; Higgins \& Nicholl, 2003; Brown, 1975), model microteaching dalam penelitian ini cenderung lebih terbuka dan diseting mendekati suasana pembelajaran yang sesungguhnya. Pada fokus keterampilan, misalnya, kegiatan microteaching ini menyasar keterampilan-keterampilan yang memang diperlukan untuk menjalankan pembelajaran yang berpusat pada siswa, seperti keterampilan dalam merancang masalah pembelajaran, keterampilan dalam mengelola diskusi kelompok dan diskusi kelas, keterampilan membuka dan menutup pembelajaran yang relevan dengan pembelajaran yang berpusat pada siswa dan keterampilan lainnya.

Pada aspek jumlah siswa, model microteaching ini dirancang dengan memperhatikan aspek psikologis peserta. Karena mengajar adalah relatif baru pertama kali dilakukan oleh peserta, maka pada microteaching tahap pertama, kegiatan microteaching dilaksanakan dalam kelompok kecil (6-7 peserta per kelompok). Hal ini bertujuan untuk meminimalisir kompleksitas proses pembelajaran bagi guru pemula sehingga peserta dapat lebih mudah mengikuti dan menguasai fokus keterampilan microteaching yang dicanangkan. Kemudian, berbekal pengalaman kegiatan microteaching pada tahap pertama, kegiatan microteaching pada tahap kedua dirancang lebih menyerupai suasana kelas normal, dimana jumlah peserta yang berperan menjadi siswa menjadi 12 - 14 peserta per kelompok. Hal ini bertujua untuk melatih keterampilan peserta dalam melaksanakan dan menghadapi pembelajaran dalam suasana kelas yang lebih menyerupai suasana pembelajaran di sekolah pada umumnya.

Pada aspek waktu, durasi pelaksanaan pembelajaran dalam model microteaching dalam penelitian ini dilaksanakan dalam waktu 35 - 40 menit. Durasi waktu ini relatif cukup untuk melaksanakan pembelajaran yang berpusat pada siswa secara utuh dengan tujuan pembelajaran yang spesifik. Berbeda dengan model microteaching D. Allen yang mengalokasikan sekitar 10 menit untuk melaksanakan pembelajaran (Brown, 1975). Durasi tersebut tentu belum cukup untuk melaksanakan pembelajaran secara utuh, akan tetapi cukup untuk melaksanakan pembelajaran secara parsial, misalnya praktik membuka atau mengakhiri 
pembelajaran saja. Akan tetapi, suatu proses pembelajaran tidak dapat dipandang secara parsial, karena setiap tahapan dalam pembelajaran saling terkait antara yang satu dengan yang lainnya. Hal ini didasarkan pada keyakinan bawha bahwa suatu proses pembelajaran merupakan suatu proses yang holistik dan kompleks yang umumnya terdiri atas kegiatan awal, inti, dan akhir pembelajaran, dimana satu kegiatan dengan kegiatan lainnya saling berkaitan dan menilai kualitas pembelajaran tidak dapat dilahat dari satu tahapan saja melainkan proses pembelajaran seutuhnya (Suparman, 2014; Putrawangsa, 2013).

Karakteristik lainnya dari model microteaching dalam penelitian ini adalah sifatnya yang lebih mandiri, yaitu kegiatan pelatihan mengajar yang dilakukan oleh sekelompok pembelajar mandiri (Self-Study Group). Dalam kegiatan microteaching ini, peserta saling mengevaluasi dengan cara berganti peran secara bergilir, yaitu sebagai guru dan observer. Dalam hal ini, yang dipantau, pemantau, penilai dan pemberi masukan dilakukan oleh anggota peserta microteaching (Peer Supervision). Dalam hal ini, kehadiran seorang ahli/pakar tidak menjadi suatu keharusan. Hal ini bukan berarti bahwa seorang ahli tidak diperlukan dalam model kegiatan ini, melainkan ketidakhadiran ahli bukan menjadi penghalang pelaksanaan kegiatan microteahing dalam model ini. Akan tetapi, ahli dapat dihadirkan jika memang diperlukan keberadaanya. Model microteaching seperti ini oleh Allen dan Wang (1996) diistilahkan dengan sebutan Peer Microteaching, yaitu suatu kegiatan microteaching yang dilakukan oleh sekelompok pembelajar mandiri (Self-Study Group) dimana peserta dalam kelompok tersebut saling menilai (Peer Supervision).

Karakteristik lainnya dari model microteaching dalam penelitian ini adalah adanya protokol observasi dan evaluasi yang digunakan untuk mengevaluasi kegiatan microteaching yang kemudian diperkenalkan dengan istilah $G \& C$ Protocol. Pada awal perkembangannya, kegiatan microteaching belum memiliki protokol evaluasi yang jelas, sehingga setiap peserta menyampaikan feedback secara elaboratif tanpa fokus yang cenderung sulit untuk ditemukan poin evaluasi yang ingin disampaikan (Allen dan Wang, 1996). Selain itu, evaluasi seperti ini cenderung lebih mengungkap sisi negatif dari guru (kelemahan, kekurangan, kesalahan, dll) yang berdampak negatif terhadap psikologis guru (Allen dan Wang, 1996). Oleh karena itu, sejumlah protokol evaluasi kegiatan microteaching dikembangkan oleh para ahli, misalnya the 2+2 Evaluation Protocol oleh Allen dan Wang (1996). Akan tetapi protokol ini masih memiliki kelemahan, yaitu banyaknya saran yang masuk sehingga mempersulit guru dalam mengorganisir dan mengaplikasikannya. Hal ini dikarenakan the 2+2 Evaluation Protocol mengharuskan masing-masing observer untuk memberikan penilaian terhadap guru yang terdiri atas: 2 pujian (hal yang merupakan sisi positif dari penampilan guru) dan 2 saran (hal 
yang perlu diperbaiki dari penampilan guru). Jika terdapat 6 orang observer, maka kemungkinan akan ada 12 masukan yang perlu diperhatikan oleh guru. Berbeda dengan the $2+2$ Evaluation Protocol, G\&C Protocol mengarahkan observer dalam tim (bukan setiap individu) berdiskusi untuk menyampaikan 2 atau 3 hal penting yang baik dari penampilan guru yang sangat perlu untuk dipertahankan atau ditingkatkan dan 2 atau 3 hal yang sangat penting dan urgen untuk diperbaiki dari penampilan guru. 2 atau 3 aspek negatif dari guru tersebut kemudian didiskusikan bersama untuk menemukan solusinya. Sehingga, dalam satu kali microteaching guru dapat lebih fokus untuk memperbaiki 2 atau 3 aspek dari kelemahannya pada saat itu juga (at-the-time improvement).

Karakteristik lainnya dari model microteaching dalam penelitian ini adalah melekatnya unsur didaktik pada pengaturan dan pedoman pelaksanaan model microteaching ini. Pengaturan yang sifatnya didaktik ini kemudian diistilahkan dengan Didactical Microteaching Setting. Istilah didactical dipinjam dari istilah didactical phenomenology oleh Freudenthal (2002) untuk menjelaskan bagaimana suatu penomena dapat dirancang untuk dijadikan sebagai alat atau media untuk membelajarkan orang lain. Dengan makna yang tidak jauh berbeda, Didactical Microteaching Setting dalam model microteaching ini merujuk pada pengaturan kegiatan microteaching sedemikian sehingga aturan tersebut dapat membelajarkan peserta tentang aspek-aspek dari pengajaran beserta kompleksitasnya. Misalnya, perubahan jumlah siswa pada microteaching tahap pertama dan kedua sengaja dilakukan agar siswa secara bertahap diarahkan untuk menghadapi suasana pembelajaran yang lebih kompleks dan normal. Contoh lainnya adalah pemilihan tujuan dan materi pembelajaran yang sesuai dengan level siswa. Hal ini ditujukan agar guru dapat merasakan problematika sesungguhnya dari siswa dalam pembelajaran dimana dari hal tersebut guru belajar menghadapinya.

Secara umum, efektivitas model microteaching ini untuk menanamkan keterampilan mahasiswa calon guru dalam melaksanakan pembelajaran berpusat pada siswa adalah kontribusi dari protokol (pedoman dan aturan) kegiatan microteaching yang relevan dengan karakteristik model pembelajaran berpusat pada siswa. Misalnya, pada perancangan dan pelaksanaan pembelajaran, peserta diarahkan untuk merancang dan melaksanakan pembelajaran yang relevan dengan model pembelajaran berpusat pada siswa, yaitu pembelajaran yang berbasis masalah dalam suasana kolaboratof-interaktif (Anthony, 1996; Weltman, 2007). Selain itu, protokol evaluasi diarahkan untuk mengevaluasi aspek-aspek penting terkait dengan keterampilan melaksanakan pembelajaran berpusat pada siswa, seperti keterampilan merancang dan menyajikan masalah serta keterampilan mengelola diskusi 
kelompok dan kelas. Protokol tersebut secara langsung melatih peserta untuk memiliki keterampilan melaksanakan pembelajaran berpusat pada siswa.

\section{SIMPULAN}

Berdasarkan uraian di atas, dapat disimpulkan bahwa karakteristik kegiatan model microteaching untuk membangun keterampilan mahasiswa calon guru matematika dalam melaksanakan pembelajaran berpusat pada siswa antara lain: (1) Kegiatan microteaching dilaksanakan dalam siklus kegiatan perencanaan, pelaksanaan, observasi, dan evaluasi pembelajaran student centered dimana setiap peserta berganti peran sebagai guru dan penilai; (2) Kegiatan microteaching dilaksanakan dalam bentuk peer microteaching oleh sekelompok pembelajar mandiri (self-study group) dimana mereka saling menilai (peer supervision); (3) Kegiatan microteaching memiliki protokol observasi dan evaluasi guru yang dilakukan oleh diri peserta (self evaluation) dan sejawat (peer evaluation) serta fokus pada aspek penampilan mengajar guru terkait dengan keterampilan melaksanakan pembelajaran berpusat pada siswa yang dianggap sangat penting dan mungkin untuk diperbaiki pada saat kegiatan microteaching berlangsung (at-the-time improvement); dan (4) Kegiatan microteaching dilaksanakan dalam suasana pembelajaran dengan kompleksitas yang progresif, yaitu mulai dari mengejar pada kelas dengan pengaturan kompleksitas rendah ke tinggi.

\section{DAFTAR PUSTAKA}

Akker, J. V. D., Gravemeijer, K., McKenney, S., \& Nieveen, N. (2006). Educational Design Research. Oxon: Routledge.

Allen, D. \& Wang, W. (1996). Microteaching. China: Xinhua Press.

Altuk, Y.G., Kaya, V. H., and Bahceci, D. (2012). A Study on developing "Microteaching scale" for student teachers. Procedia - Social and Behavioral Sciences, 2964 - 2969.

Anthony, G. (1996). Active Learning in a Constructivist Framework. New York: Kluwer Academic Publishers.

Bell, N. D. (2007). Microteaching: What is it that is going on here?" Linguistics and Education, Hal. 24-40.

Brown, G. (1975) Microteaching a programme of teaching skill. London: Metheun

Ferna'ndez, M. L. (2010). Investigating how and what prospective teachers learn through microteaching. Teaching and Teacher Education, 2010: 351-362.

Freudenthal, H. (2002) Didactical Phenomenology of Mathematical Structures. New York: Kluwer Academic Publisher.

Higgins, A., \& Nicholl, H. (2003). The experiences of lecturers and students in the use of microteaching as a teaching strategy. Nurse Education in Practice, 2003: 220-227.

Karçkay, A. T., \& Sanl, S. (2009). The effect of micro teaching application on the preservice teachers' teacher competency levels. Procedia Social and Behavioral Sciences, 2009: 844-847. 
Koc, B., \& Ilya, A. (2016). Exploring Pre-service Language Teachers' Perceptions and Actual Practices of Giving Feedback in Micro-teaching. Procedia - Social and Behavioral Sciences, 2016: 421 - 429.

McKenney, S., \& Reeves, T. C. (2012). Conducting Educational Design Research. Oxon: Routledge.

McNamara, O., Roberts, L., Basit, T., \& Brown, T. (2002). Rites of passage in initial teacher training: Ritual performance, ordeal and numeracy skills test. British Educational Research Journal, 2002: 863-878.

Mendikbud (2016). Peraturan Menteri Pendidikan dan Kebudayaan Republik Indonesia Nomor 21 Tahun 2016 tentang Standar Isi Pendidikan Dasar dan Menengah. Jakarta: Menteri Pendidikan dan Kebudayaan Republik Indonesia.

Mendiknas (2006). Peraturan Menteri Penddidikan Nasional Republik Indonesia No. 22 Tahun 2006 tentang Standar Isi untuk Satuan Pendidikan Dasar dan Menengah. Jakarta: Menteri Pendidikan Nasional Republik Indonesia

Singapore Ministry of Education (2012). Primary Mathematics Teaching and Learning Syllabus. Singapore: Singapore Ministry of Education.

NCTM (2000) Principles and Standars for School Mathematics. Reston, VA: National Council of Teacher of Mathematics.

Negara, H., R., P. \& Putrawangsa, S. (2017). Pengembangan Model Praktikum Untuk Mengembangkan Keterampilan Mahasiswa Calon Guru dalam Penilaian Pembelajaran. Jurnal Tatsqif, 15(2), Retrieved from: http://ejurnal.iainmataram.ac.id/ index.php/tatsqif/article/view/1465

Plomp, T., \& Nieveen, N. (2010). An Introduction to Educational Design Research. Enschede: SLO-Netherlands Institute for Curriculum Development,

Putrawangsa, S. (2013). Educational Design Research: Developing Students' Understanding of The Multiplication Strategy in Area Measurement. Master Thesis. Surabaya: Universitas Negeri Surabaya

Putrawangsa, S., Lukito, A., Amin, S.M., \& Wijers, M. (2013) Educational Design Research: Developing Students' Understanding of Area as the Number of Measurement Units Covering a Surface. Dalam Zulkardi (Eds.) The First South East Asia Design/Development Research (SEA-DR) International Conference 416 426. Palembang: Eprint Unsri

Suparman, M.A. (2014). Desain Instruksional Modern (Edisi Keempat). Jakarta: Airlangga

Weltman, D. (2007) A Comparison of Traditional and Active Learning Methods: An Empirical Investigation Utilizing a Linear Mixed Model. PhD Thesis, Arlington: The University of Texas. 